\title{
A bibliometric analysis of scientific production in the field of lingual orthodontics
}

\author{
Beatriz Tarazona-Alvarez ${ }^{1}$, Rut Lucas-Dominguez ${ }^{2}$, Vanessa Paredes-Gallardo ${ }^{3^{*}}$ (D), Adolfo Alonso-Arroyo ${ }^{2}$ and \\ Antonio Vidal-Infer ${ }^{2}$
}

\begin{abstract}
Background: Due to the lack of bibliometric studies in the field of lingual orthodontics in dentistry, the aim of this study was to assess the evolution and current status of activity in this field during the period 1978-2017.

Methods: A bibliometric analysis of the scientific articles indexed in the Science Citation Index-Expanded of the Web of Science and in the Scopus ${ }^{\circledast}$ database was performed using the truncated terms "ling* apppli*" or "ling* orthod*" or "ling* bracket*". The types of texts included for analysis were limited to "articles" and "reviews". The following information was extracted from each article identified: title, authors' name(s), institutional affiliation(s), country of origin, journal title, year of publication, type of publication, and number of citations.

Results: A total of 341 articles were identified by 646 different authors, $6.2 \%$ were reviews and $93.8 \%$ were other types of journal articles. Bibliometric indicators showed a tremendous increase in the rate of publication over time with two peaks in productivity in 1989 and 2013. Fourteen authors and 15 institutional collaboration networks were identified in which European institutions were the most productive. Methodological articles were the most frequent types of research articles (28.1\%), followed by case reports/series (17.1\%), and narrative reviews (4.7\%). Articles providing the highest quality evidence were interventional clinical trials (1.8\%) and systematic reviews (0.9\%). The remaining articles were non-research papers and were for information purposes only.

Conclusions: Bibliometric indicators point to an irregular increase in the numbers of published works in lingual orthodontics over time. Research output is dominated by methodological articles as a technique-driven subspecialty. Although articles on lingual orthodontics are published mainly in North American journals, lingual orthodontics is largely a European domain.
\end{abstract}

Keywords: Bracket, Bibliometric, Lingual, Orthodontics

\section{Background}

The increase in demand by adults for orthodontic treatment has been mirrored by an increased availability and demand for aesthetic treatments such as lingual appliances [1]. Despite being available for over 30 years, it is perhaps only over the past decade or so that lingual therapy has entered mainstream practice and become more widely accepted as a viable treatment option for

\footnotetext{
* Correspondence: Vanessa.paredes@uv.es

${ }^{3}$ Orthodontics Teaching Unit, Department of Dental Medicine, Faculty of Medicine and Dentistry, University of Valencia, C/ Gasco Oliag 1, 46010 Valencia, Spain

Full list of author information is available at the end of the article
}

treating most malocclusions, and as a suitable alternative to conventional labial appliances [2]. Clinically improved laboratory techniques have overcome many of the difficulties that a previous generation of orthodontists encountered when they first tried to apply this innovative technique [3]. In addition to the aesthetic advantages of lingual appliances, they have also been shown to reduce the risk of enamel decalcification in comparison with labial brackets and to guarantee high precision in treatment outcomes [4].

Demand has not only increased among adult patients but since the introduction of completely customized

(c) The Author(s). 2019 Open Access This article is distributed under the terms of the Creative Commons Attribution 4.0 International License (http://creativecommons.org/licenses/by/4.0/), which permits unrestricted use, distribution, and 
lingual appliances, a growing number of adolescents are now being treated with lingual techniques [4].

Bibliometrics is the analysis of a set of literature to show the historical development of subject fields and patterns of authorship, publication, and use. The most common bibliometric indicators are based on the scientific productivity of researchers, organizations, and countries. This usually aims to measure the impact of research published in journals, on the basis of the number of citations a paper receives, regarded as a measure of the paper's importance [5].

In recent years, only three bibliometric studies have been published investigating publication trends in orthodontic research [5-8] but none of them have specifically investigated the field of lingual orthodontics. The first [7] analyzed the 100 most cited articles in orthodontics from 1975 to 2011; the second [6] explored and compared the publications in three major orthodontic journals over two 5-year periods; the latest [8], identified the most cited articles from 2000 to 2015 based on the h-index. Unlike analyses of other dental specialties such as implant dentistry [9] or oral surgery [10], none of these three studies made a complete and rigorous analysis.

Given the lack of bibliometric studies of research in the specific field of lingual orthodontics, the aim of this study was to assess the evolution and current status of scientific activity in this specific field during the period 1978-2017 through a bibliometric analysis of the scientific articles indexed in the Science Citation IndexExpanded of the Web of Science (Clarivate Analytics, 1500 Spring Garden St, Philadelphia, United States) and in the Scopus ${ }^{\circ}$ database (Elsevier B.V. Radarweg 29, 1043 NX Amsterdam, Netherlands).

\section{Materials and methods}

\section{Search strategy}

The search was conducted in two databases, and aimed to identify the entire body of scientific production in the field of lingual orthodontics: the Science Citation IndexExpanded of the Web of Science (SCI) and the Scopus ${ }^{\circ}$ database. Both were selected on the basis of their broad thematic and geographic coverage of health sciences.

In the SCI database, the search was conducted employing the terms "ling" apppli"", or "ling" orthod", or "ling" bracket" in the topic field, and two inclusion criteria were applied: firstly, only documents denominated as articles or reviews were included; and secondly, and only articles categorized as Medicine, Dentistry, and Oral Surgery were included.

In the Scopus ${ }^{\circ}$ database, the following search equation was applied containing the same terms used as the SCI: TITLE-ABS-KEY (["ling" apppli" OR "ling* orthod"” OR "ling* bracket"”]) AND (LIMIT-TO [DOCTYPE, "ar"]) OR (LIMIT-TO [DOCTYPE, "re"]).

The field selected in the Scopus ${ }^{\oplus}$ database (Title, Abstract, Keywords) was equivalent to the field "Topic" in the SCI. In Scopus ${ }^{\oplus}$, the results were limited to articles and reviews, and only papers about dentistry were included. Non-English papers were excluded.

Both searches were performed in June 2018 and the period covered was defined by the earliest published research in lingual orthodontics in 1978 (first document obtained) to 2017.

The Impact Factor (IF) of each article was calculated to evaluate the impact of the journals in the SCI. The IF is calculated by dividing the number of citations in the Journal Citation Reports database year by the total number of articles published in the two previous years.

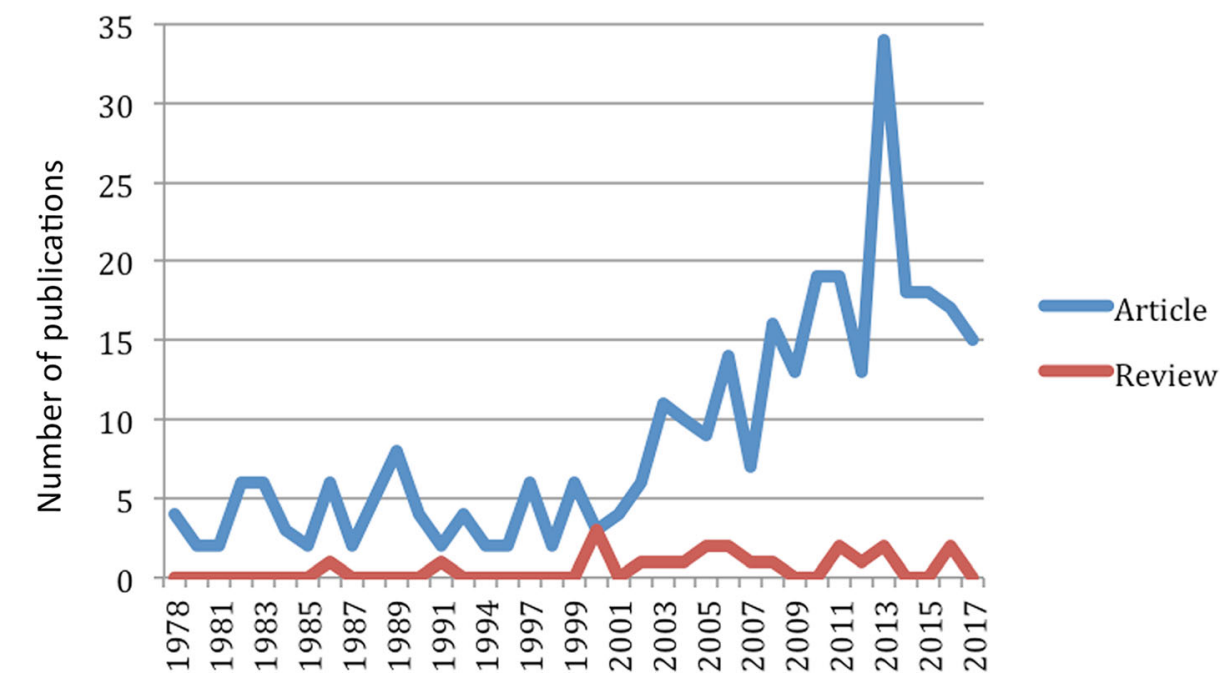

Fig. 1 Annual evolution of scientific production from 1978 to 2018 (other types of journal articles in blue and reviews in red). The x-axis indicates year(s) of publication, and the $y$-axis the total numbers of publications 
Table 1 The most productive authors with more than five published articles appearing in the $\mathrm{SCl}$ and $\mathrm{Scopus}^{\circledR}$ databases

\begin{tabular}{lllllll}
\hline & & \multicolumn{2}{l}{ SCl } & & \multicolumn{2}{l}{ Scopus } \\
\cline { 7 - 8 } \cline { 6 - 7 } Authors & Total Articles & Articles & Cites & & Articles & Cites \\
\hline Wiechmann D & 32 & 11 & 111 & 26 & 412 \\
Fillion D & 16 & 1 & 13 & 16 & 133 \\
Schwestka-Polly R & 14 & 10 & 97 & 11 & 90 \\
Hohoff A & 12 & 6 & 86 & 9 & 158 \\
Geron S & 11 & 5 & 55 & 10 & 107 \\
Scuzzo G & 10 & 1 & 0 & 10 & 41 \\
Stamm T & 10 & 5 & 63 & 8 & 145 \\
Fujita K & 9 & 1 & 41 & 8 & 118 \\
Lombardo L & 9 & 0 & 0 & 9 & 31 \\
Siciliani G & 9 & 0 & 0 & 9 & 31 \\
Ehmer U & 8 & 4 & 52 & 7 & 129 \\
Hong RK & 7 & 2 & 40 & 7 & 74 \\
Bourauel C & 6 & 5 & 8 & 5 & 11 \\
Gorman JC & 6 & 1 & 11 & 6 & 85 \\
Seong-Hun K & 6 & 3 & 12 & 4 & 15 \\
Macchi A & 6 & 0 & 0 & 6 & 12 \\
Takemoto K & 6 & 0 & 0 & 6 & 22 \\
\hline
\end{tabular}

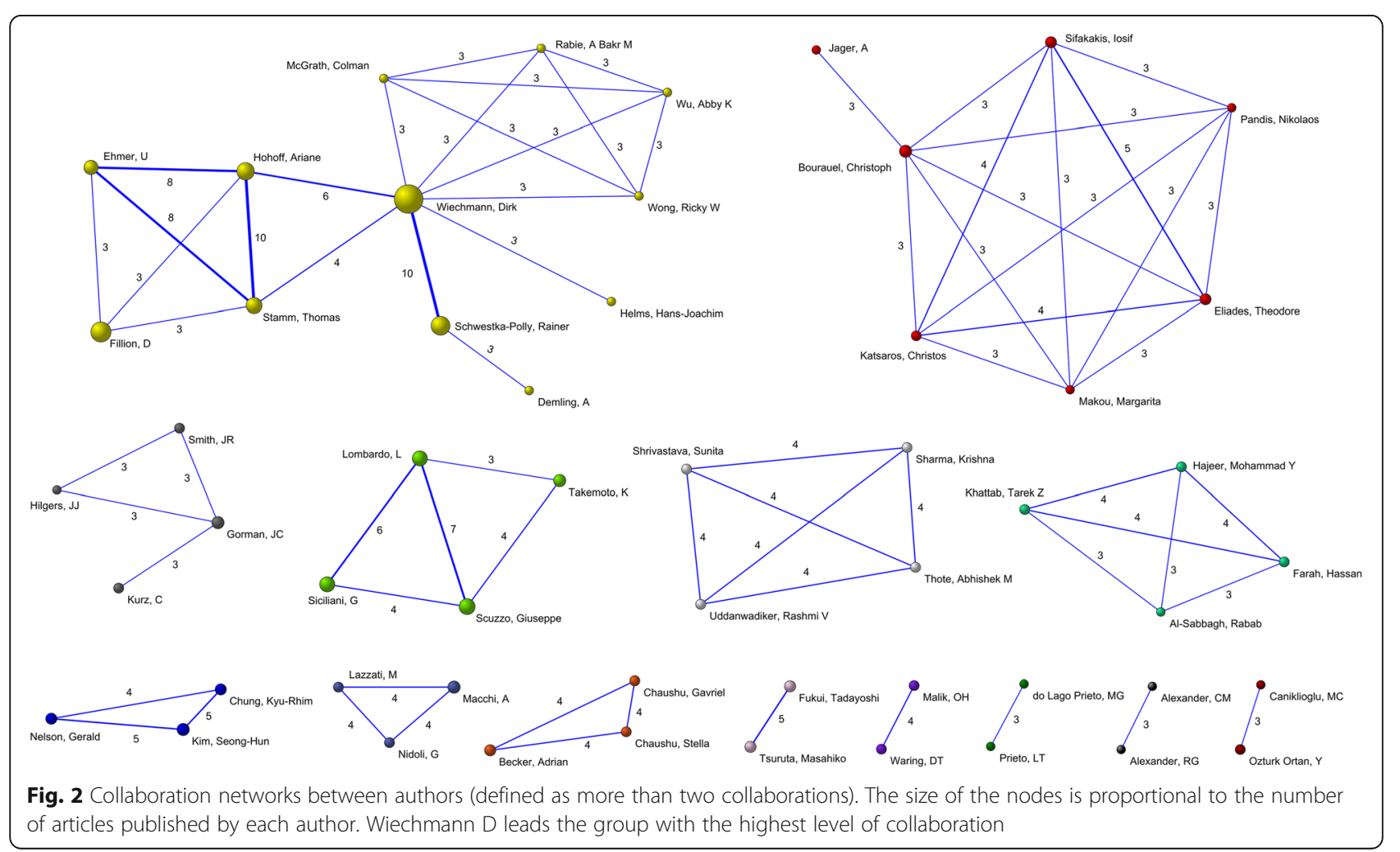

The impact of journals in Scopus ${ }^{\circ}$ was assessed by their rank in the Scimago Journal \& Country Rank (SJR) database. The SJR is calculated by indicating the average number of weighted citations received during a selected year per document published in that journal during the previous three years.

\section{Data collection}

The following information was extracted from each article identified: title, authors' name(s), institutional affiliation(s), country of origin, journal title, year of publication, type of publication, and number of citations.

Records were manually refined and normalized to unify terms and to remove typographical, transcription, and/or indexing errors; normalization was completed in the fields "Author," "Organization," and "Country of Origin." Normalization was complicated by the numbers of different entries for a single author. In these cases, the institutional affiliations of the authors were consulted to check whether different entries belonged to the same author. If this information was not available, an Internet search was carried out to eliminate potential error. Normalization of organizations followed the same procedure. Only macro-organizations (i.e., Universities, and research centers) were included, discarding microorganizations, such as individual departments or research units. When the same organization signed the 
same work more than once, it was only counted once. The "country" field was also normalized.

\section{Data analysis}

Descriptive analysis of variables and crosstables were performed using Microsoft Access database and Excel software (One Microsoft Way Redmond, WA 980526399, USA).

The evolution of scientific productivity by authors, organizations, countries and journals was assessed, as well as the frequency of the appearance of keyword categories. Analysis and visualization of large networks were performed using Pajek software [11].

For the determination of the type (observational clinical trials, laboratory studies and case reports or series, reviews, interviews, systematic reviews, informative studies and others) and quality of the study, the content of the articles has been analyzed through the information available in the title and summary. The quality of the studies was assessed on the basis of methodological parameters such as the presence of a control group, the number of patients included, as well as statistical analysis.

\section{Results}

The annual evolution of the scientific production is shown in Fig. 1. The 40-year period 1978-2017includes the publication of 341 articles, which were placed in order according to the publication date (Fig. 1). Of 341 selected articles, 316 articles were found in Scopus ${ }^{\circ}, 90$ in SCI and 65 were available in both Scopus $^{\bullet}$ and SCI database.

The selected 341 articles were written by 641 different authors. The average number of author per paper was 3.3. Seventy percent of authors $(n=452)$ were responsible for a single work, $17 \%(n=109)$ for two works, and the remaining $13 \%(n=85)$ for more than two works.

Table 2 The most productive institutions and countries with more than three published articles appearing in the $\mathrm{SCl}$ and $\mathrm{Scopus}{ }^{\oplus}$ databases

\begin{tabular}{|c|c|c|c|c|c|c|}
\hline \multirow[b]{2}{*}{ Institution } & \multirow[b]{2}{*}{ Country } & \multirow[b]{2}{*}{ Total Articles } & \multicolumn{2}{|l|}{$\mathrm{SCl}$} & \multicolumn{2}{|l|}{ Scopus $^{\circledast}$} \\
\hline & & & Articles & Citations & Articles & Citations \\
\hline Muenster University Hospital & Germany & 25 & 12 & 138 & 18 & 357 \\
\hline Hannover Medical School & Germany & 15 & 7 & 51 & 14 & 121 \\
\hline Tel Aviv University & Israel & 14 & 7 & 66 & 11 & 113 \\
\hline Private practice Bad Essen & Germany & 13 & 6 & 32 & 12 & 188 \\
\hline University of Ferrara & Italy & 10 & 1 & 0 & 10 & 37 \\
\hline Kyung Hee University & South Korea & 8 & 5 & 14 & 6 & 17 \\
\hline University of Bern & Switzerland & 7 & 5 & 23 & 6 & 49 \\
\hline University of Bonn & Germany & 7 & 6 & 17 & 6 & 16 \\
\hline University of Athens & Greece & 6 & 5 & 11 & 5 & 12 \\
\hline University of Zurich & Switzerland & 6 & 5 & 44 & 5 & 38 \\
\hline Chong-A Dental Hospital & South Korea & 5 & 2 & 40 & 5 & 72 \\
\hline Hebrew University & Israel & 5 & 3 & 13 & 3 & 22 \\
\hline Istanbul University & Turkey & 5 & 2 & 21 & 5 & 43 \\
\hline University of California San Francisco & USA & 5 & 3 & 12 & 3 & 11 \\
\hline Okayama University & Japan & 4 & 3 & 32 & 3 & 36 \\
\hline Seoul National University & South Korea & 4 & 4 & 12 & 4 & 13 \\
\hline Sharad Pawar Dental College & India & 4 & 3 & 2 & 3 & 2 \\
\hline Universidade Estadual Paulista (UNESP) & Brazil & 4 & 1 & 0 & 4 & 3 \\
\hline University of Al-Baath Dental School & Syria & 4 & 1 & 12 & 3 & 16 \\
\hline University of Barcelona & Spain & 4 & 1 & 13 & 4 & 23 \\
\hline University of Dusseldorf & Germany & 4 & 2 & 20 & 2 & 13 \\
\hline University of Goettingen & Germany & 4 & 4 & 10 & 3 & 5 \\
\hline University of Paris VII & France & 4 & 0 & 0 & 4 & 98 \\
\hline University of Paris-Descartes & France & 4 & 1 & 13 & 4 & 47 \\
\hline Visvesvaraya National Institute of Technology & India & 4 & 3 & 2 & 3 & 2 \\
\hline
\end{tabular}




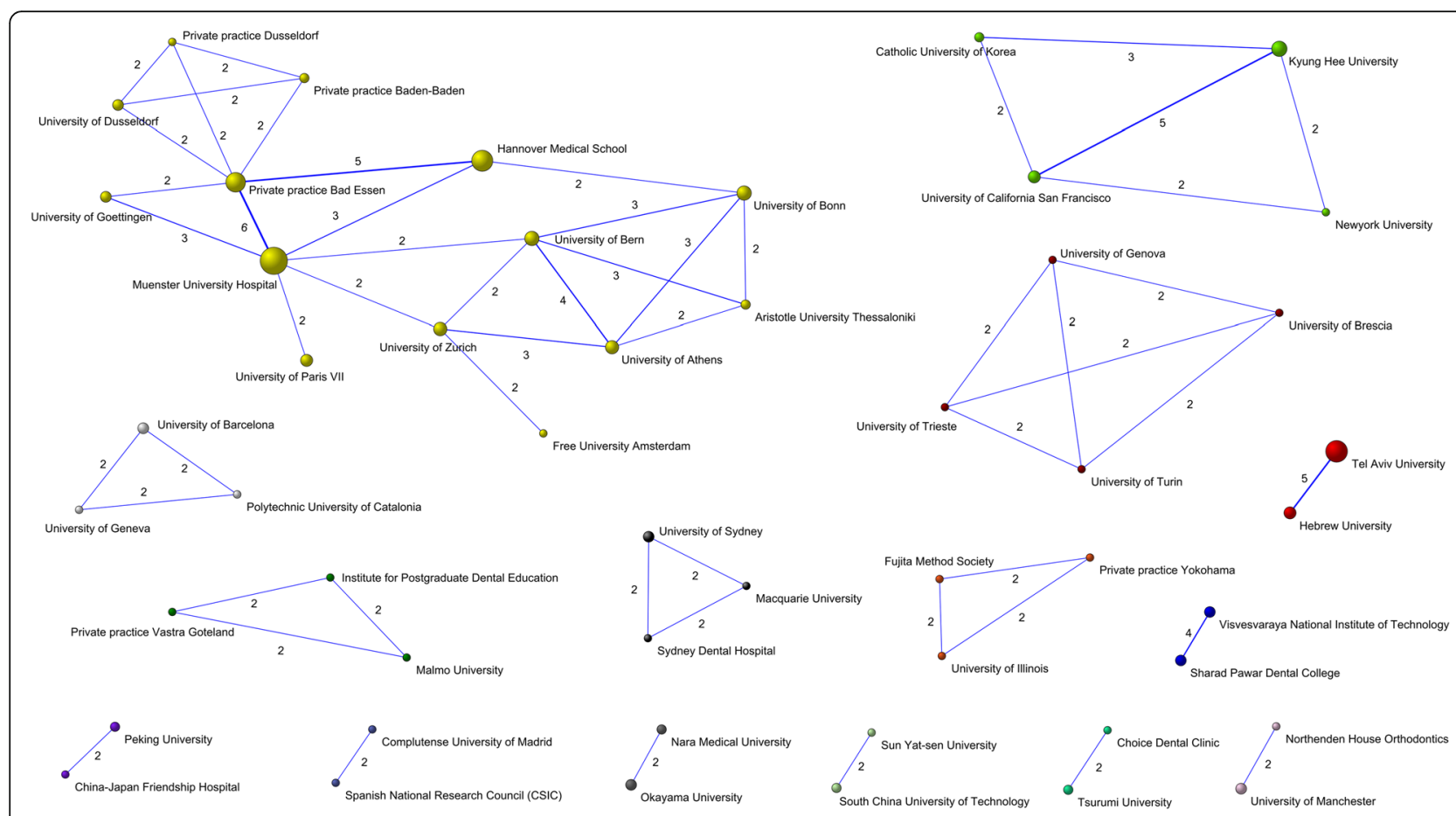

Fig. 3 Collaboration networks between institutions (defined as more than one collaboration). The size of the nodes is proportional to the number of articles published by each institution. Muenster University Hospital is located at the core of the most important network

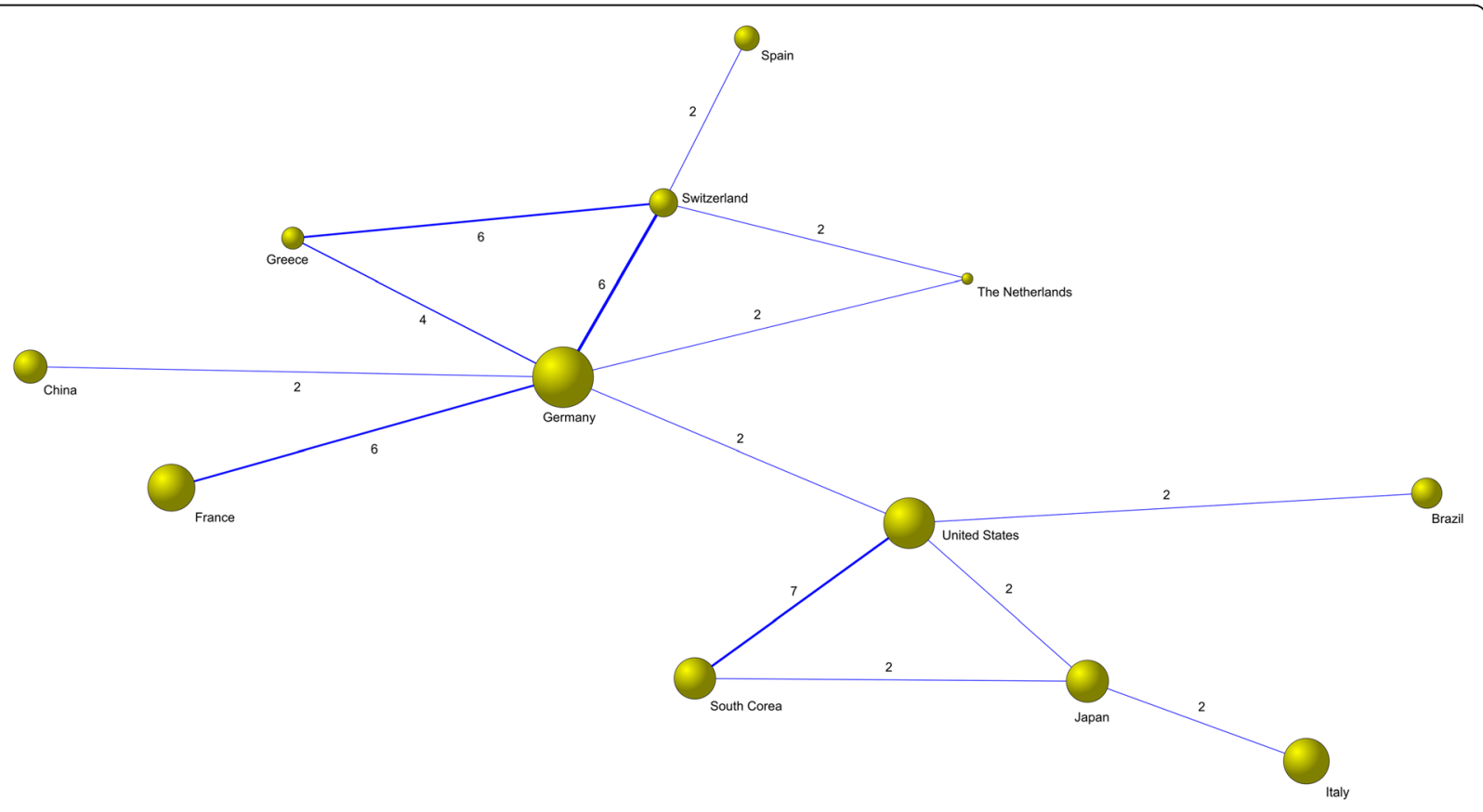

s.

Fig. 4 Collaboration networks between countries (defined as more than one collaboration). The size of the nodes is proportional to the number of articles published by each country. Germany followed by the USA are the central countries in the network 
Those authors with more than five publications $(n=17)$ are shown in Table 1.

Based on the Pajek algorithym, 14 author collaboration networks were identified (Fig. 2). The size of the nodes is proportional to the number of articles published by each author. The largest network consists of 12 authors led by Wiechmann Dbeing the most productive author with 32 publications. The same network includes three other notably productive authors: Fillion D, SchwestkaPolly $R$ and Hohoff A. Each of these authors form part of the two most productive networks, linked through Wiechmann D. Twelve of the most productive authors belonged to collaboration networks.

The most productive institutions $(n=25)$ and their nationalities (which were the same nationalities as all the authors with more than three published works) are shown in Table 2. The Muenster University Hospital is in the first place with 25 articles.

Collaborations between institutions (defined as more than one collaboration between institutions) obtaining a total of 15 collaboration networks are illustrated in Fig. 3. These networks are made up of 450 institutions, the most extensive being led by Muenster University Hospital in collaboration with 13 other institutions, most of them German institutions.

Regarding countries, the most productive countries with more than 20 articles published by national authors were Germany (58 articles), Italy (28 articles), South Korea (28 articles) and United States (23 articles). However, Germany and United Stateswere the two countries participating in the most collaboration works (Fig. 4).

Table 3 Distribution of journals with more than one published article in JCR (Journal Citation Reports) and SJR (Scimago Journal \& Country Rank)

\begin{tabular}{|c|c|c|c|c|c|c|c|c|}
\hline \multirow[b]{2}{*}{ Scientific Journal } & \multicolumn{4}{|c|}{$\begin{array}{l}\text { JCR category (Dentistry, Oral Surgery } \\
\text { \& Medicine) }\end{array}$} & \multicolumn{4}{|c|}{ SJR category (miscellaneous) } \\
\hline & Articles & Cites & IF $^{\mathrm{a}} 2016$ & Quartile $^{\mathrm{b}} \mathrm{JCR}$ & Articles & Cites & SJR 2016 & Quartile $^{\mathrm{b}}$ SJR \\
\hline Journal of clinical Orthodontics & - & - & - & - & 39 & 313 & 0.285 & Q3 $(1751 / 2864)$ \\
\hline American Journal of Orthodontics and Dentofacial Orthopedics & 19 & 206 & 1.472 & Q2 (44/90) & 23 & 358 & 1.265 & Q1 (2/19) \\
\hline International Orthodontics & - & - & - & - & 20 & 52 & 0.299 & Q3 (11/19) \\
\hline \multirow[t]{2}{*}{ Angle Orthodontist } & 18 & 198 & 1.366 & Q3 (52/90) & 18 & 256 & 1.216 & Q1 (3/19) \\
\hline & & & & & & & & Q1 (427/2864) \\
\hline \multirow[t]{3}{*}{ Journal of Orofacial Orthopedics } & - & - & - & - & 16 & 265 & 0.613 & Q2 (1094/2864) \\
\hline & & & & & & & & Q2 (8/19) \\
\hline & & & & & & & & Q3 (23/44) \\
\hline European Journal of Orthodontics & 12 & 65 & 1.622 & Q2 (36/90) & 13 & 83 & 1.134 & Q1 (4/19) \\
\hline Journal of Orthodontics & - & - & - & - & 13 & 20 & 0.578 & Q2 (9/19) \\
\hline L' Orthodontie francaise & - & - & - & - & 13 & 32 & 0.182 & Q3 (2088/2864) \\
\hline Seminars in Orthodontics & - & - & - & - & 10 & 27 & 0.293 & Q3 (12/19) \\
\hline Progress in Orthodontics & - & - & - & - & 8 & 31 & 1.352 & Q1 (1/19) \\
\hline Korean Journal of Orthodontics & 7 & 14 & 1.182 & Q3 (62/90) & 7 & 16 & 0.850 & Q2 (7/19) \\
\hline \multirow[t]{2}{*}{ Dental Press Journal of Orthodontics } & - & - & - & - & 7 & 3 & 0.467 & Q2 (10/19) \\
\hline & & & & & & & & Q3 (28/44) \\
\hline \multirow[t]{4}{*}{ Head and Face Medicine } & 6 & 47 & 1.370 & Q3 (51/90) & 5 & 24 & 0.584 & Q2 (1175/2864) \\
\hline & & & & & & & & Q2 (50/138) \\
\hline & & & & & & & & Q3 (193/364) \\
\hline & & & & & & & & Q2 (50/110) \\
\hline \multirow[t]{3}{*}{ Journal of Oral and Maxillofacial Surgery } & 2 & 6 & 1.916 & Q2 (31/90) & 2 & 7 & 0.883 & Q3 (13/44) \\
\hline & & & & & & & & Q1 (16/110) \\
\hline & & & & & & & & Q1 (95/420) \\
\hline Journal of Esthetic and Restorative Dentistry & 2 & 2 & 1.273 & Q3 (58/90) & 3 & 7 & 0.808 & Q1 (24/138) \\
\hline
\end{tabular}

aIF Impact Factor

${ }^{\mathrm{b}}$ Quartile = Distribution of the ranked journals in the JCR/SJR categories into four classes with each containing one fourth of the IF/SJR distribution of this category, whereas Q1 contains the highest and Q4 the lowest IF/SJR

- not indexed in the database 
The scientific journals with more than one work published according to the SCI and Scopus ${ }^{\bullet}$ databases are shown in Table 3. Both databases (SCI and SJR) complement one another but are not comparable since the number of journals and the means of calculating rankings are different. A distribution in classes (quartiles) may be a convenient way of comparing journal rankings across different databases (Tab. 3).

The most cited articles are shown in Table 4. Articles that have received the most citations registered in the SCI and Scopus", referred to as "hot papers". Kinya Fujita, inventor of the lingual bracket technique, tops the list.

A classification of the articles according to the type of study is shown in Table 5. Laboratory studies (methodological articles) are the most frequent type of research paper $(28.1 \%)$, followed by case reports/series (17.1\%), and narrative reviews (4.7\%). The highest quality evidence in the field of lingual orthodontics is provided by interventional clinical trials and systematic reviews but these only represent a tiny proportion of all published works: 1.8 and $0.9 \%$ respectively.

\section{Discussion}

To address the nonexistence of bibliometric studies in the field of lingual orthodontics, the aim of this study was to assess the evolution and current status of research activity during the period 1978-2017.

The present study adopted a thorough selection process, applying several search terms ("ling* apppli*" or "ling* orthod" or "ling* bracket") and detailed inclusion criteria to identify relevant articles in the SCI and Scopus $^{\circ}$ databases, which were then ranked by the number of citations received by each one.

Regarding the evolution of scientific production, some dental specialities such as Implantology [5] or Periodontics [10] have undergone increasing growth in the quantity of published research in recent years. But the field of lingual orthodontics (with 341 original studies) has followed a different pattern, with increased production up to the year 1989 followed by a fall. More recently, between 2003 and 2017, research activity has taken off again with 2013 seeing the highest number of published works ever (34 articles). This could be due to the general increased demand for orthodontic treatment by adults,

Table 4 Articles with highest numbers of citations registered in the $\mathrm{SCl}$ and $\mathrm{Scopus}{ }^{\oplus}$ database

\begin{tabular}{|c|c|c|c|}
\hline \multirow[b]{2}{*}{ Articles } & & \multicolumn{2}{|c|}{ Cites } \\
\hline & & $\overline{\mathrm{SCl}}$ & Scopus $^{\oplus}$ \\
\hline Fujita K New orthodontic treatment with lingual bracket mushroom arch wire appliance & Am J Orthod. 1979; 76 (6): 657-675 & 41 & 66 \\
\hline $\begin{array}{l}\text { Van der Veen MH, Attin R, Schwestka-Polly R, Wiechmann D Caries outcomes after orthodontic } \\
\text { treatment with fixed appliances: do lingual brackets make a difference? }\end{array}$ & Eur J Oral Sci. 2010; 118 (3): 298-303 & 31 & 0 \\
\hline $\begin{array}{l}\text { Hong RK, Heo JM, Ha YK Lever-arm and mini-implant system for anterior torque control during } \\
\text { retraction in lingual orthodontic treatment }\end{array}$ & Angle Orthod. 2005; 75 (1): 129-141 & 31 & 38 \\
\hline $\begin{array}{l}\text { Wiechmann D, Schwestka-Polly R, Pancherz H, Hohoff A Control of mandibular incisors with the } \\
\text { combined Herbst and completely customized lingual appliance - a pilot study }\end{array}$ & Head Face Med. 2010;6:3. & 23 & 0 \\
\hline Creekmore T Lingual orthodontics - its renaissance & $\begin{array}{l}\text { Am J Orthod Dentofacial Orthop. } \\
\text { 1989; } 96 \text { (2): 120-137 }\end{array}$ & 22 & 32 \\
\hline $\begin{array}{l}\text { Geron S, Shpack N, Kandos S, Davidovitch M, Vardimon AD Anchorage loss - A multifactorial } \\
\text { response }\end{array}$ & Angle Orthod. 2003; 73 (6): 730-737 & 21 & 33 \\
\hline $\begin{array}{l}\text { Miyawaki S, Yasuhara M, Koh Y Discomfort caused by bonded lingual orthodontic appliances in } \\
\text { adult patients as examined by retrospective questionnaire }\end{array}$ & $\begin{array}{l}\text { Am J Orthod Dentofacial Orthop. } \\
\text { 1999; } 115 \text { (1): 83-88 }\end{array}$ & 21 & 31 \\
\hline $\begin{array}{l}\text { Geron S, Romano R, Brosh T Vertical forces in labial and lingual orthodontics applied on } \\
\text { maxillary incisors - A theoretical approach }\end{array}$ & Angle Orthod. 2004; 74 (2): 195-201 & 20 & - \\
\hline Pauls AH Therapeutic Accuracy of Individualized Brackets in Lingual Orthodontics & $\begin{array}{l}\text { J Orofac Orthop. 2010; } 71 \text { (5): 348- } \\
361\end{array}$ & 20 & - \\
\hline Stamm T, Hohoff A, Ehmer U A subjective comparison of two lingual bracket systems & Eur J Orthod. 2005; 27 (4): 420-426 & 19 & - \\
\hline $\begin{array}{l}\text { Wiechmann D, Rummel V, Thalheim A, Simon JS, Wiechmann L Customized brackets and } \\
\text { archwires for lingual orthodontic treatment }\end{array}$ & $\begin{array}{l}\text { Am J Orthod Dentofacial Orthop. } \\
\text { 2003; } 124 \text { (5): 593-599 }\end{array}$ & - & 53 \\
\hline $\begin{array}{l}\text { Baxter J Competing discourses in the classroom: A post-structuralist discourse analysis of girls' } \\
\text { and boys' speech in public contexts }\end{array}$ & $\begin{array}{l}\text { Discourse Society 2002; } 13 \text { (6): 827- } \\
842\end{array}$ & - & 52 \\
\hline $\begin{array}{l}\text { Wiechmann D A new bracket system for lingual orthodontic treatment. Part 1: Theoretical } \\
\text { background and development }\end{array}$ & $\begin{array}{l}\text { J Orofac Orthop. 2002; } 63 \text { (3): 234- } \\
245\end{array}$ & - & 40 \\
\hline Wiechmann D Lingual orthodontics (part 1): laboratory procedure & $\begin{array}{l}\text { J Orofac Orthop. 1999; } 60 \text { (5): 371- } \\
379\end{array}$ & - & 36 \\
\hline Fujita K Multilingual-bracket and mushroom arch wire technique. A clinical report & Am J Orthod. 1982; 82 (2): 120-140 & - & 34 \\
\hline
\end{tabular}


Table 5 Articles with highest numbers of citations (hot papers) registered in the SCl and Scopus database (The empty cells mean that those articles have not received citations in that database)

\begin{tabular}{|c|c|c|c|c|}
\hline Authors & Title & Journal & $\begin{array}{l}\text { Cites } \\
\text { SCl }\end{array}$ & $\begin{array}{l}\text { Cites } \\
\text { SCOPUS }\end{array}$ \\
\hline Fujita, K & $\begin{array}{l}\text { New orthodontic treatment with lingual bracket } \\
\text { mushroom arch wire appliance }\end{array}$ & $\begin{array}{l}\text { American Journal of Orthodontics and } \\
\text { Dentofacial Orthopedics 1979; } 76 \text { (6): } \\
657-675\end{array}$ & 41 & 66 \\
\hline $\begin{array}{l}\text { van der Veen, MH; Attin, R; } \\
\text { Schwestka-Polly, R; Wiech- } \\
\text { mann, D. }\end{array}$ & $\begin{array}{l}\text { Caries outcomes after orthodontic treatment with fixed } \\
\text { appliances: do lingual brackets make a difference? }\end{array}$ & $\begin{array}{l}\text { European Journal of Oral Sciences 2010; } \\
118 \text { (3): 298-303 }\end{array}$ & 31 & \\
\hline Hong, RK.; Heo, JM.; Ha, YK. & $\begin{array}{l}\text { Lever-arm and mini-implant system for anterior torque } \\
\text { control during retraction in lingual orthodontic } \\
\text { treatment }\end{array}$ & $\begin{array}{l}\text { Angle Orthodontist 2005; } 75 \text { (1): 129- } \\
141\end{array}$ & 31 & 38 \\
\hline $\begin{array}{l}\text { Wiechmann, D; Schwestka- } \\
\text { Polly, R; Pancherz, H; Hohoff, } \\
\text { A. }\end{array}$ & $\begin{array}{l}\text { Control of mandibular incisors with the combined Herbst } \\
\text { and completely customized lingual appliance - a pilot } \\
\text { study }\end{array}$ & Head \& Face Medicine 2010; Mar 11;6:3. & 23 & \\
\hline Creekmore, $T$ & Lingual orthodontics - its renaissance. & $\begin{array}{l}\text { American Journal of Orthodontics and } \\
\text { Dentofacial Orthopedics 1989; } 96 \text { (2): } \\
\text { 120-137 }\end{array}$ & 22 & 32 \\
\hline $\begin{array}{l}\text { Geron, S; Shpack,N; Kandos, S; } \\
\text { Davidovitch, M; Vardimon, AD. }\end{array}$ & Anchorage loss - A multifactorial response & $\begin{array}{l}\text { Angle Orthodontist 2003; } 73 \text { (6): } 730- \\
737\end{array}$ & 21 & 33 \\
\hline $\begin{array}{l}\text { Miyawaki, S; Yasuhara, M; Koh, } \\
\text { Y. }\end{array}$ & $\begin{array}{l}\text { Discomfort caused by bonded lingual orthodontic } \\
\text { appliances in adult patients as examined by retrospective } \\
\text { questionnaire. }\end{array}$ & $\begin{array}{l}\text { American Journal of Orthodontics and } \\
\text { Dentofacial Orthopedics 1999; (): 83-88 }\end{array}$ & 21 & 31 \\
\hline Geron, S; Romano, R; Brosh, T. & $\begin{array}{l}\text { Vertical forces in labial and lingual orthodontics applied } \\
\text { on maxillary incisors - A theoretical approach }\end{array}$ & $\begin{array}{l}\text { Angle Orthodontist 2004; } 74 \text { (2): 195- } \\
201\end{array}$ & 20 & \\
\hline Pauls, AH. & $\begin{array}{l}\text { Therapeutic Accuracy of Individualized Brackets in } \\
\text { Lingual Orthodontics }\end{array}$ & $\begin{array}{l}\text { Journal of Orofacial Orthopedics- } \\
\text { fortschritte Der Kieferorthopadie 2010; } \\
71 \text { (5): 348-361 }\end{array}$ & 20 & \\
\hline Stamm, T; Hohoff,A; Ehmer, U. & A subjective comparison of two lingual bracket systems & $\begin{array}{l}\text { European Journal of Orthodontics 2005; } \\
27 \text { (4): } 420-426\end{array}$ & 19 & \\
\hline $\begin{array}{l}\text { Wiechmann, D; Rummel, V; } \\
\text { Thalheim, A; Simon, JS; } \\
\text { Wiechmann, L. }\end{array}$ & $\begin{array}{l}\text { Customized brackets and archwires for lingual } \\
\text { orthodontic treatment }\end{array}$ & $\begin{array}{l}\text { American Journal of Orthodontics and } \\
\text { Dentofacial Orthopedics 2003; } 124 \text { (5): } \\
\text { 593-599 }\end{array}$ & & 53 \\
\hline Baxter, J. & $\begin{array}{l}\text { Competing discourses in the classroom: A post- } \\
\text { structuralist discourse analysis of girls' and boys' speech } \\
\text { in public contexts }\end{array}$ & $\begin{array}{l}\text { Discourse \& Society 2002; } 13 \text { (6): 827- } \\
842\end{array}$ & & 52 \\
\hline Wiechmann, D. & $\begin{array}{l}\text { A new bracket system for lingual orthodontic treatment. } \\
\text { Part 1: Theoretical background and development }\end{array}$ & $\begin{array}{l}\text { Journal of Orofacial Orthopedics- } \\
\text { fortschritte Der Kieferorthopadie 2002; } \\
63 \text { (3): 234-245 }\end{array}$ & & 40 \\
\hline Wiechmann, D. & Lingual orthodontics (part 1): laboratory procedure. & $\begin{array}{l}\text { Journal of Orofacial Orthopedics- } \\
\text { fortschritte Der Kieferorthopadie 1999; } \\
60 \text { (5): } 371-379\end{array}$ & & 36 \\
\hline Fujita, K. & $\begin{array}{l}\text { Multilingual-bracket and mushroom arch wire technique. } \\
\text { A clinical report }\end{array}$ & $\begin{array}{l}\text { American Journal of Orthodontics 1982; } \\
82 \text { (2): } 120-140\end{array}$ & & 34 \\
\hline
\end{tabular}

the appearance on the market of new lingual orthodontic systems, and clinically improved laboratory techniques. Review articles remained constant during this period with no increase. Most of the works identified were research articles and were found in the Scopus ${ }^{\oplus}$ database.

Most of the authors published only one work. Of those with more than five published works, Wiechmann $D$ was the most productive and outstanding among the other authors, with a total of 32 published works, double the number published by Fillion $D$ (16 works), in second place. But on the basis of the number of citations received by each article, another different author, Fujita $K$, is notable for the 41 citations registered in the Journal Citation Report (JCR) database [12] for his 9 works.

As for the number of authors per work, the average was 3.3, a lower average than in other dental specialities such as implantology with an average of 4.66 [9] or periodontics with an average of 5.1 [13] and a much lower average than other medical fields such as cardiology with an average of 10.5 authors per work [14]. Nevertheless, the number of authors per work has increased from an average of 1.6 to 4.2 in recent years, an evolution that corresponds to other medical fields due to the 
multidisciplinary nature of much recent research activity [15]. One work was found to lack definite authorship, one had ten authors, and 95 works were published just by a single author.

Most institutions; 164, produced only one published work and only 10 institutions published more than five. Regarding the types of institution, most were universities and hospitals, with the exception of one private practice in Bad Essen (Germany) associated with the most productive author, Wiechmann D. European institutions German and French - head the list, unlike other dental specialities in which most research activity takes place in North American institutions $[9,16]$.

The most productive authors worked in institutions in 12 different countries. The most productive countries were European, with Germany doubling Italy and South Korea in second and third place. As with the institutions publishing research, contrary to other specialities, USA is not among the three most productive nations.

All the articles included in the present analysis were published in 94 scientific journals indexed in SCI or Scopus $^{\circ}$ databases, or in both. The three scientific journals with most published works and citations registered in both databases were: The Journal of Clinical Orthodontics, The American Journal of Orthodontics and Dentofacial Orthopedics and The Angle Orthodontist, while some articles were published in scientific journals that only appeared in one database. A possible explanation is that these three scientific journals are popular, highly respected journals in orthodontics with a high impact factor that per se can influence the authors' decision about where to publish. Another parameter to be considered is the frequency of publication of orthodontic journals (American Journal of Orthodontics and Dentofacial Orthopedics, 12 issues per year; The Angle Orthodontist and The Journal of Clinical Orthodontics, 6 issues per year), which increases the amount of content (number of articles) and boosts readership among dentistry professionals.

Not all the articles in our study were published in journals specializing in orthodontics; some were published in journals dealing with other dental specialities such as surgery or esthetic and restorative dentistry with high impact factors as noted by other authors [8].

This reflects the increasingly multidisciplinary nature of treatments involving orthodontics especially in adult patients, and the need to maximize the impact of orthodontic research.

Among the most cited articles or "hot papers," one article by Fujita $K$ [11] published in 1979 stands out with 41 citations in both the SCI and Scopus ${ }^{\circ}$ databases, unlike other cited articles whose citations do not appear in both databases. The reason for the high number of citations may be because it was published many years ago; obviously older works may have received more citations simply because they have been available for longer. Generally, citations to papers peak in the second, third, or fourth year after publication, but some papers continue to be cited for many years. A few papers can exhibit delayed recognition. Patterns can vary depending on the type of paper, the field, and the findings reported. Papers reporting methods or techniques can gradually increase in citation frequency over several years as the methods diffuse through the community and prove their utility.

The majority of the analyzed articles were primary research articles; mainly, observational clinical studies, laboratory studies and case reports. Only a small percentage of articles corresponded to secondary research articles (reviews, systematic reviews or metaanalyses).

\section{Conclusions}

The bibliometric indicators point to an irregular increase in the numbers of published works in lingual orthodontics over time. Research output is dominated by methodological articles as a technique-driven subspecialty. The number of articles is generally lower compared with other dental or medical specialties, which include several research fields.

\section{Acknowledgements \\ The authors thank William James Packer, professional English language editor, for translating the manuscript.}

\section{Authors' contributions}

BT and VP carried out the literature search. BT, VP, RL, AA and AV screened the titles and abstracts and extracted data from full text articles. BT and VP manually refined and normalized data to unify the terms applied to all articles. RL and AV performed data synthesis. AA carried out the statistical analysis and prepared the main part of the manuscript. BT, VP, RL and AV contributed to the analysis, interpretation of data and writing of the manuscript. All authors approved the final version of the manuscript and accept accountability for all aspects of the work, declaring that questions related to the accuracy or integrity of all parts of the work have been appropriately investigated and reported.

\section{Funding}

The corresponding author states no financial or other relationships with other people or organizations, which may lead to a conflict of interest.

\section{Availability of data and materials}

The datasets used and/or analyzed during the current study are available from the corresponding author upon reasonable request.

Ethics approval and consent to participate

Not applicable.

Consent for publication

Not applicable.

Competing interests

The authors declare that they have no competing interests.

\section{Author details}

'Orthodontics Teaching Unit, Department of Dental Medicine, Faculty of Medicine and Dentistry, University of Valencia, Valencia, Spain. ${ }^{2}$ UISYS Research Unit (UV-CSIC), Department of History of Science and Information 
Science, School of Medicine and Dentistry, University of Valencia, Valencia, Spain. ${ }^{3}$ Orthodontics Teaching Unit, Department of Dental Medicine, Faculty of Medicine and Dentistry, University of Valencia, C/ Gasco Oliag 1, 46010 Valencia, Spain.

Received: 10 June 2019 Accepted: 2 September 2019

Published online: 07 September 2019

\section{References}

1. Sharif MO, Waring D, Malik OH. Lingual orthodontics: the future? Int J Orthod Milwaukee. 2015;26:49-52.

2. George RD, Hirani S. Fully-customized lingual appliances: how lingual orthodontics became a viable treatment option. J Orthod. 2013;40(Suppl 1): S8-13. https://doi.org/10.1179/ortho/40.s1.s8.

3. Chatoo A. A view from behind: a history of lingual orthodontics. J Orthod. 2013;40(Suppl 1):S2-7. https://doi.org/10.1179/ortho/40.s1.s2.

4. Beyling F, Schwestka-Polly R, Wiechmann D. Lingual orthodontics for children and adolescents: improvement of the indirect bonding protocol. Head Face Med. 2013;9:27. https://doi.org/10.1186/1746-160X-9-27.

5. Jayaratne YSN, Zwahlen RA. The evolution of dental journals from 2003 to 2012: a bibliometric analysis. PLoS One. 2015;10:e0119503. https://doi.org/ 10.1371/journal.pone.0119503. eCollection 2015.

6. Baumgartner S, Pandis N, Eliades T. Exploring the publications in three major orthodontic journals. A comparative analysis of two 5-year periods. Angle Orthod. 2014;84:397-403. https://doi.org/10.2319/071113-507.1 Epub 2013 Oct 3.

7. Hui J, Han Z, Geng G, Yan W, Shao P. The 100 top-cited articles in orthodontics from 1975 to 2011. Angle Orthod. 2011;83:491-9. https://doi. org/10.2319/0003-3219-83.2.366.

8. Prevezanos P, Tsolakis Al, Christou P. Highly cited orthodontic articles from 2000 to 2015. Am J Orthod Dentofac Orthop. 2018;153:61-9. https://doi.org/ 10.1016/j.ajodo.2017.06.015.

9. Tarazona B, Vidal-Infer A, Alonso-Arroyo A. Bibliometric analysis of the scientific production in implantology (2009-2013). Clin Oral Implants Res. 2017;28:864-70. https://doi.org/10.1111/clr.12891 Epub 2016 Jun 3.

10. Aslam-Pervez N, Lubek JE. Most cited publications in oral and maxillofacial surgery: a bibliometric analysis. Oral Maxillofac Surg. 2018;22:25-37. https:// doi.org/10.1007/s10006-017-0660-z Epub 2017 Nov 4.

11. de Nooy W, Mrvar A, Batagelj V. Exploratory social network analysis with Pajek: revised and expanded edition for updated software. 3rd ed. New York: Cambridge University Press; 2018.

12. Fujita K. New orthodontic treatment with lingual bracket and mushroom archwire appliance. Am J Orthod. 1979;76:657-75.

13. Geminiani A, Ercoli C, Feng C, Caton JG. Bibliometrics study on authorship trends in periodontal literature from 1995 to 2010. J Periodontol. 2014;85: e136-43. https://doi.org/10.1902/jop.2013.130354 Epub 2013 Nov 11.

14. Khan MS, Usman MS, Fatima K, Hashmani N, Siddiqi TJ, Riaz H, Khan AR, Khosa F. Characteristics of highly cited articles in interventional cardiology. Am J Cardiol. 2017;120:2100-9. https://doi.org/10.1016/j.amjcard.2017.08.030 Epub 2017 Aug 31.

15. Bueno-Aguilera F, Jiménez-Contreras E, Lucena-Martín C, Pulgar-Encinas R. Dental research in Spain. A bibliometric analysis on subjects, authors and institutions (1993-2012). Med Oral Patol Oral Cir Bucal. 2016;21:e142-50.

16. Zyoud SH, Al-Jabi SW, Sweileh WM, Al-Khalil S, Alqub M, Awang R. Global methaemoglobinaemia research output (1940- 2013): a bibliometric analysis. Springerplus. 2015;19:626. https://doi.org/10.1186/s40064-015-14317. eCollection 2015.

\section{Publisher's Note}

Springer Nature remains neutral with regard to jurisdictional claims in published maps and institutional affiliations.

Ready to submit your research? Choose BMC and benefit from:

- fast, convenient online submission

- thorough peer review by experienced researchers in your field

- rapid publication on acceptance

- support for research data, including large and complex data types

- gold Open Access which fosters wider collaboration and increased citations

- maximum visibility for your research: over $100 \mathrm{M}$ website views per year

At BMC, research is always in progress.

Learn more biomedcentral.com/submissions 